\title{
The effect of some pre-roasting treatments on quality characteristics of pumpkin seed oil
}

\author{
Nesimi Aktaş*, Kamil Emre Gerçekaslan and Türkan Uzlaşır \\ Nevşehir Hacı Bektaş Veli University, Faculty of Engineering Architecture, Department of Food Engineering, 50300 Nevşehir, Turkey
}

Received 22 July 2017 - Accepted 20 March 2018

\begin{abstract}
In this study, the pumpkin seed oils used were obtained from roasted and unroasted seeds of the two varieties called "Nevşehir Çerçevelisi" and "Ürgüp Sivrisi", belonging to the species Cucurbita pepo. Oil extraction, from seeds subjected to three different pretreatments (unsalted, dry salted and wet salted) before roasting and sun-dried unroasted seeds, was carried out by means of a screw press. Pumpkin seed oils were analyzed for quality and antioxidant characteristics. The p-anisidine, peroxide and TBARS (thiobarbutiric acid reactive substances) values of oils obtained from sun-dried unroasted seeds and roasted seeds after wet salting process were lower than the other sample groups $(p<0.05)$. The obtained oils were rich in $\mathrm{Zn}, \mathrm{Fe}, \mathrm{Mg}$, Se, $\mathrm{Ca}, \mathrm{K}$ and $\mathrm{Na}$ minerals, and palmitic, stearic, oleic and linoleic fatty acids. In the oils, $\beta+\gamma$ tocopherols content ranged from 131.78 to $881.77 \mathrm{mg} / \mathrm{kg}$ oil, $\delta$-tocopherol content ranged from 3.22 to $8.67 \mathrm{mg} / \mathrm{kg}$ oil. Total phenolic matter content ranged from 1.35 to $3.62 \mathrm{mg}$ gallic acid equivalent (EAG)/g. $\mathrm{ABTS}^{+}$radical scavenging activity of the oils obtained from sun-dried-unroasted seeds and roasted seeds after wet salting process was determined higher than the other oil samples $(p<0.05)$.
\end{abstract}

Keywords: pumpkin seed oil / tocopherol / total phenolic content / antioxidant activity / fatty acid

Résumé - L’effet de certains traitements de pré-torréfaction sur les caractéristiques qualitatives de I'huile de graines de courges. Dans cette étude, ont été utilisées des huiles de graines de courges obtenues à partir de graines toastées ou non issues des deux variétés appelées «Nevşehir Çerçevelisi » et «Ürgüp Sivrisi », appartenant à l'espèce Cucurbita pepo. L'extraction d'huile, à partir de graines soumises à trois prétraitements différents (non salées, salées «à sec » et salées en saumure) avant le toastage et de graines non grillées séchées au soleil, a été réalisée au moyen d'une presse à vis. Les huiles de graines de citrouille ont été analysées pour leur qualité et leurs caractéristiques antioxydantes. Les valeurs, des indices de p-anisidine, et peroxyde et de TBARS (substances réagissant avec l'acide thiobarbutirique) des huiles obtenues à partir de graines non grillées séchées au soleil et des graines toastées après salage humide, étaient inférieures aux autres échantillons $(p<0,05)$. Les huiles obtenues étaient riches en $\mathrm{Zn}, \mathrm{Fe}, \mathrm{Mg}, \mathrm{Se}, \mathrm{Ca}, \mathrm{K}$ et $\mathrm{Na}$, et en acides gras palmitique, stéarique, oléique et linoléique. Dans les huiles, la teneur en $\beta+\gamma$ tocophérols variait de 132 à $882 \mathrm{mg} / \mathrm{kg}$ d'huile et la teneur en $\delta$-tocophérol se situait entre $3,2 \mathrm{et} 8,7 \mathrm{mg} / \mathrm{kg}$ d'huile. La teneur en matière phénolique totale variait de 1,35 à 3,62 mg d'équivalent d'acide gallique (EAG) par g. L'activité de piégeage, des radicaux ABTS + des huiles obtenues à partir de graines non toastées séchées au soleil et de graines grillées après salage humide, s'est révélée plus élevée que les autres échantillons d'huile $(p<0,05)$.

Mots clés : huile de graines de citrouille / tocophérol / teneur totale en composés phénoliques / activité antioxydante / acide gras

\section{Introduction}

Pumpkin is a member of Cucurbitaceae family, and various cultivars are grown throughout the world. C. moschata,

*Correspondence: naktas@nevsehir.edu.tr
C. maxima, C. pepo, and C. mixta are the most common commercially important species (Saucedo-Hernandez et al., 2011; Prevc et al., 2013). C. moschata is the most important cultivar in Tropical America. It has spread in central America and Mexico and these areas have become the center of variety. The origin of $C$. maxima, which is considered to be one of the oldest cultivars, is South America. This variety is being 
cultivated since pre-Colombian times (Veronezi and Jorge, 2012). The most common pumpkin species grown in Turkey is C. pepo. This species is mostly grown in Nevşehir, which is at the centre of Cappadocia, one of the seven regions named in the world heritage list. 12746 tons of the 41612 tons of pumpkin seed produced as snack in Turkey were grown in Nevşehir (TUIK, 2016). This corresponds to approximately $31 \%$ of the total production.

Pumpkin seeds as a rich source of bioactive components have been used as functional food or medicine. The seeds are used to overcome enterozoa and prostate problems in Austria, Slovenia, Serbia, Argentina, India, Mexico, Brazil, Korea and China (Pericin et al., 2009; Adams et al., 2012; Kim et al., 2012). In addition, the seeds have hypoglycaemic effect as well as antioxidant, anticancer and anti-inflammatory effects (Veronezi and Jorge, 2012; Prevc et al., 2013; Rabrenovic et al., 2014). Pumpkin seeds are consumed as snacks in some countries, in raw form or in salted roasted form (El-Adawy and Taha, 2001; Prevc et al., 2013). Pumpkin seed and oil are also used as an ingredient in baked products and salads (Juranovic et al., 2003; Nawirska-Olszanska et al., 2013).

Pumpkin seed oil is a type of oil that is commercially available in Austria, Slovenia and Hungary (Pericin et al., 2009; Prevc et al., 2013). This oil is also an important product in Japan, Czech Republic, Germany, Romania, Italy, North and South Ukraine (Oloyede et al., 2012a).

Pumpkin seed oil is used as cooking oil in some North African and Middle-Eastern countries (El-Adawy and Taha, 2001). As the oil is rich in oleic and linoleic acids, this oil may be used as cooking and salad oil, and it is also suitable for margarine production (El-Adawy and Taha, 2001; Stevenson et al., 2007; Jiao et al., 2014).

Traditionally, pumpkin seed oil is obtained by pressing the roasted pumpkin seeds while the cold pressed pumpkin seed oil is obtained by pressing the unroasted pumpkin seeds. These two oils have different sensory characteristics such as color, taste and odor. Studies on oils obtained from roasted seeds reveal that these oils are rich sources of mono and polyunsaturated fatty acids, vitamins, minerals, phytosterols, pigments, pyrazine derivatives and phenolic compounds (Xanthopoulou et al., 2009; Kim et al., 2012; Veronezi and Jorge, 2012). For this reason, pumpkin seed oil is not only an edible oil but it also attracts interest as a potential nutraceutical oil. An essential fatty acid, linoleic acid, has been determined in pumpkin seed oil, which is an indication that this oil is an important type of oil in terms of health. El-Adawy and Taha (2001) expressed that linoleic acid reduces serum cholesterol level. Based on experimental studies, risk of lipid peroxidation may increase with high $(>11 \%)$ polyunsaturated fatty acids consumption, particularly when tocopherol intake is low. Therefore, the recommended range for polyunsaturated fatty acids is $6-11 \%$ of energy. There are some recommendations for the balance between omega- 6 and omega- 3 polyunsaturated fatty acids. In the German-Austrian-Swiss recommendations, the effective ratio is $5: 1$ and it is mentioned that an unbalanced ratio may affect the further metabolism (FAO, 2010).

No studies have been conducted to determine the effect of different pre-treatments applied to the seeds, before the roasting process, on the characteristic properties of the pumpkin seed oil. Thus, the aims of this study were:
- to determine the characteristics of the oil extracted from pumpkin seeds that have been sun-dried-unroasted, unsalted-roasted, dry salted-roasted and wet salted roasted; - to reveal the most suitable process.

\section{Materials and methods}

\subsection{Materials}

Two types of pumpkin seeds, called "Nevşehir çerçevelisi" and "Ürgüp sivrisi", belonging to C. pepo species were used in the study. After being procured from the manufacturer, these seeds have been cleaned and divided into four portions of $20 \mathrm{~kg}$ each. One of these portions was sun-dried during the month of October before being packed in a polyethylene bag and stored at $15^{\circ} \mathrm{C}$ until oil extraction took place. This group was used as the sun-dried unroasted group. For the second portion, 2\% water was added into the seeds and stirred, and then $5 \%$ salt $(\mathrm{w} /$ w) was added and stirred thoroughly again to ensure a homogenous distribution. The mixture was then roasted at $175^{\circ} \mathrm{C}$ for $15 \mathrm{~min}$ in a multilayer belt forced air convection roasting oven (Sevval SRX90, Denizli, Turkey). The seeds layer thickness was $2.5 \mathrm{~cm}$. This group was designed as the dry-salted-roasted group. To the third portion, $2 \%$ water was added into the seeds and stirred, and then the mixture was roasted at $175^{\circ} \mathrm{C}$ for $15 \mathrm{~min}$ in a multilayer belt roasting oven. This group was designed as the unsalted-roasted group. For seeds of the fourth portion, $3.3 \%$ water was added into the seeds and stirred, and then $4.3 \%$ salt was added and stirred thoroughly again to ensure a homogenous distribution. The mixture was kept overnight, and then roasted at $175^{\circ} \mathrm{C}$ for $15 \mathrm{~min}$ in a multilayer belt roasting oven. This group was designed as the wet salted-roasted group. After the roasting processes, seeds were packed in polyethylene bags and stored at $15^{\circ} \mathrm{C}$ until the oil extraction process took place. The moisture contents of Nevşehir çerçevelisi (sun-driedunroasted), Nevșehir çerçevelisi (wet salted-roasted), Nevșehir çerçevelisi (dry salted-roasted), Nevşehir çerçevelisi (unsalted-roasted), Ürgüp sivrisi (sun-dried-unroasted), Ürgüp sivrisi (wet salted-roasted), Ürgüp sivrisi (dry salted-roasted), and Ürgüp sivrisi (unsalted-roasted) prior to oil expression were determined $5.74 \pm 0.03, \quad 3.11 \pm 0.28, \quad 1.87 \pm 0.34$, $1.87 \pm 0.24,5.36 \pm 0.02,3.64 \pm 0.66,2.77 \pm 0.56,2.30 \pm 0.12$, respectively.

\subsection{Methods}

\subsubsection{Oil extraction}

Oil extractions from different sample groups were made in low temperature by using a screw press (Koçmaksan, KMS10, Izmir, Turkey). The head section of the screw press was heated to $75^{\circ} \mathrm{C}$ before pressing started, by using a specially designed heating ring. When the system reached this temperature, seeds went through the press to produce oil. Heating process of the head section does not reflect on the temperature of extracted oil since the heaters are turned off after optimal seeds flow has been achieved. First samples of pressed oil were not collected for the safety reason. The temperature of the resulting oil was measured by using a thermocouple and it was observed that the 
temperature was below $50^{\circ} \mathrm{C}$. After $24 \mathrm{~h}$ sedimentation, the resulting oil was separated from the sediment by decantation and then the oil was placed into lidded glass jars and stored in a dark room. Since the seeds called as control groups were not subjected to any roasting process, the oil obtained from this group was called as cold-pressed oil based on Nederal et al. (2014).

\subsection{Basic characteristics of the pumpkin seed oils}

\subsubsection{Specific gravity}

Specific gravities were determined at $25^{\circ} \mathrm{C}$ by using $10 \mathrm{ml}$ pycnometer.

\subsubsection{Refractive index}

Refractive indexes were determined at $25^{\circ} \mathrm{C}$ by using Abbe Refractometer (JK-ARM, Shanghai Jingke Scientific Instrument Co., Ltd., Shanghai, China).

\subsection{3 lodine value}

Iodine values were determined according to Nielson (2003).

\subsubsection{Saponification value}

Saponification values of samples were determined according to Nielson (2003).

\subsubsection{Free fatty acid}

Free fatty acid analyses were determined according to Nielson (2003). For this purpose, $5 \mathrm{~g}$ oil were weighed into a 250-ml Erlenmeyer flask and then $100 \mathrm{ml}$ neutralized ethanol (to $500 \mathrm{ml}$ of ethyl alcohol were added $2 \mathrm{ml}$ of alcoholic phenolphthalein and titrated with $0.1 \mathrm{~N} \mathrm{NaOH}$ until a faint permanent pink color is maintained) was added. The content was titrated with $0.25 \mathrm{~N} \mathrm{NaOH}$ until faint pink color persists for 1 minute. Percent free fatty acids were expressed as oleic acid.

\subsubsection{Viscosity}

Viscosity values of oils were determined at $25^{\circ} \mathrm{C}$ by using Fungilab rotating viscometer (Fungilab Alpha series, Fungilab, Barcelona, Spain) with the number of R1 spindle at $60 \mathrm{rpm}$.

\subsection{7 $p$-anisidine value}

p-anisidine values were determined according to the AOCS Official Method Cd 18-90 (AOCS, 2011).

\subsubsection{Peroxide value}

Peroxide values were determined according to Ockerman (1985).

\subsubsection{TBARS}

TBARS values of oil samples were determined according to Ke and Woyewoda (1979).

\subsection{Color}

$\mathrm{L}^{*}, \mathrm{a}^{*}$ and $\mathrm{b}^{*}$ values of oils were determined by using a colorimeter (Konica Minolta Chroma Meter CR-400, Japan).

\subsection{Mineral contents}

$\mathrm{Cu}, \mathrm{Fe}, \mathrm{Mg}, \mathrm{Mn}$ and $\mathrm{Zn}$ contents were determined by a Scott Spray chamber (Norwalk, CT, USA) ICP-MS (PerkinElmer ELAN DRC-e model) following the microwave digestion process. With this purpose, $0.1 \mathrm{~g}$ oil sample was mixed in a $6 \mathrm{ml} \mathrm{HNO}_{3}+2 \mathrm{ml} \mathrm{H}_{2} \mathrm{O}_{2}$ digestion vessel. Microwave digestion process has been realized in three stages in microwave digestion system (Berghof Speedwave Four Microwave Digestion System, Eningen, Germany). In the first stage, the temperature has been increased to reach $170^{\circ} \mathrm{C}$ from ambient temperature in 5 minutes. In the second stage, the temperature has been increased to reach $190^{\circ} \mathrm{C}$ within 5 minutes and kept at this temperature for 15 minutes. Finally, during the last stage, the temperature has been decreased to $50{ }^{\circ} \mathrm{C}$ within 21 minutes. After the cooling down to ambient temperature process, the digested samples were diluted with ultra-pure water to a volume of $25 \mathrm{ml}$. The oil-free blank samples were similarly heated and cooled down to complete in the same volume. All samples and reagent blanks had three parallels in the study. Before each trial, the tool has been tuned by using $10 \mu \mathrm{g} / \mathrm{mL}$ aqueous multi-element standard solution. The conventional sample introduction system, equipped with a cross flow nebulizer and a Scott Spray chamber, was used. The used instrumental conditions were as follows:

- autolens mode on;

- peak hopping measurement mode;

- dwell time of 50 sweeps by reading;

- one reading by 3 replicates.

Nickel sampler cone and skimmer cone were used. The radio frequency (RF) power was set to $1000 \mathrm{~W}$, the plasma gas was $19 \mathrm{~L}$ argon (Ar) $\mathrm{min}^{-1}$, the auxiliary gas flow was 1.2 $\mathrm{L} \mathrm{Armin}^{-1}$, and the nebulizer gas was $0.81 \mathrm{~L} \mathrm{Armin}^{-1}$. Analytical masses of the studied elements were ${ }^{63} \mathrm{Cu},{ }^{57} \mathrm{Fe}$, ${ }^{25} \mathrm{Mg},{ }^{55} \mathrm{Mn}$ and ${ }^{65} \mathrm{Zn}$.

$\mathrm{B}, \mathrm{Ca}, \mathrm{K}, \mathrm{Na}, \mathrm{P}$ and $\mathrm{S}$ contents were determined by ICPOES (Perkin Elmer Optima $4300 \mathrm{DV}$ ) after the microwave digestion process.

\subsection{Fatty acid composition}

The methyl esters of the fatty acids were prepared according to IUPAC (Anon, 1987) and analyzed using a Shimadzu GC-2010 Plus gas chromatograph equipped with a DB23 column ( $60 \mathrm{~m} \times 0.25 \mathrm{~mm}$ I.D. and $0.25 \mu \mathrm{m}$ film thickness) $(\mathrm{J} \& \mathrm{~W})$. Injector, column and detector temperatures were 230, 190 and $240^{\circ} \mathrm{C}$, respectively. Split ratio was 1:80. The carrier gas was helium at $1 \mathrm{ml} / \mathrm{min}$ ratio. A mix of $37 \mathrm{FAME}$ from Supelco (C4-C24) (Bellefonte, PA, USA) were used.

\subsection{Tocopherols}

Tocopherol analyses of the oils were determined according to Bele et al. (2013). The oil samples weighing $50 \mathrm{mg}$ were 
dissolved 10 times in hexane. $50 \mu$ l of this solution was taken into a screw-capped tube and diluted with $1 \mathrm{ml}$ of a mixture of methanol:hexane:tetrahydrofurane (80:10:10, v/v/v). The samples were vortexed for $5 \mathrm{~min}$ and centrifuged for $10 \mathrm{~min}$ at $5000 \mathrm{rpm}$ (Hanil Science Industrial, Model: Combi 514R). Then, the samples were filtered using nylon filters (pore sizes $0.45 \mu \mathrm{m}$, Ampel, Shanghai, China). The filtrate was directly injected into an Agilent 1260 HPLC system (Agilent Corp., Santa Clara, CA, USA). Detection was done by the fluorescence detector (excitation: $290 \mathrm{~nm}$, emission: $325 \mathrm{~nm}$ ) at an Agilent Pursuit C18 column ( $150 \times 4.6 \mathrm{~mm}, 5 \mu \mathrm{m})$. The mobile phase was a mixture of methanol and acetonitrile $(50: 50, \mathrm{v} / \mathrm{v})$, and eluted at a flow rate of $1 \mathrm{ml} / \mathrm{min}$. The tocopherols were identified by comparison of the retention times with standards of the $\alpha-, \beta-, \gamma$ - and $\delta$-tocopherols. The tocopherol contents were expressed as milligrams per $\mathrm{kg}$ oil.

\subsection{Extraction and determination of total phenolic compounds}

Total phenolic compounds of the pumpkin seed oils were extracted and determined according to Paradiso et al. (2016) with some modifications. Extraction was carried out on $2.5 \mathrm{~g}$ of oil by adding $5 \mathrm{ml}$ hexane and $5 \mathrm{ml}$ methanol/water $(80: 20 \mathrm{v} / \mathrm{v})$. After $2 \mathrm{~min}$ vortexing, and centrifugation at $6000 \mathrm{rpm}$ for $10 \mathrm{~min}$ at $4{ }^{\circ} \mathrm{C}$ (Hanil Science Industrial, Model: Combi 514R), the hydroalcoholic phase was recovered and the extraction was repeated twice. Collected hydroalcoholic phase was centrifuged at $9000 \mathrm{rpm}$ for $5 \mathrm{~min}$ at $4{ }^{\circ} \mathrm{C}$ and filtered through nylon filters (pore size $0.45 \mu \mathrm{m}$, Ampel, Shanghai, China). Then, $0.5 \mathrm{ml}$ of filtrate was added to $10 \mathrm{ml}$ volumetric flask and diluted in $5 \mathrm{ml}$ of water, followed by the addition of $0.5 \mathrm{ml}$ of Folin-Ciocalteu reagent (FCR). The mixture was incubated for $3 \mathrm{~min}$ at room temperature, and $1 \mathrm{ml}$ of $7.5 \%$ solution of $\mathrm{Na}_{2} \mathrm{CO}_{3}$ was added to the reaction mixture and volume was made up to $10 \mathrm{ml}$ with distilled water. The solutions were stored overnight and absorbance of the samples against blank read at $765 \mathrm{~nm}$ by a spectrophotometer (Thermo Fischer Scientific, Model: G10S UV-Vis). Total phenolics content was expressed as gallic acid equivalents $(\mathrm{mg} / \mathrm{g})$.

\subsection{Antioxidant activity}

$\mathrm{ABTS}^{+}$Radical Scavenging Activity analyses of the pumpkin seed oils were conducted according to the method described by Re et al. (1999). $\mathrm{ABTS}^{+}$radical was prepared by mixing ABTS stock solution ( $7 \mathrm{mM}$ in water) with $2.45 \mathrm{mM}$ potassium persulfate. This mixture was left in darkness at room temperature for $12-16 \mathrm{~h}$ before use. The $\mathrm{ABTS}^{+}$radical solution was diluted with $0.1 \mathrm{M} \mathrm{pH} 7.4$ phosphate buffer to an absorbance of $0.70( \pm 0.02)$ at $734 \mathrm{~nm}$. The reaction was started by the addition of $25,50,75$ and $100 \mu$ l of the methanolic extract of the pumpkin seed oils. The absorbance of each reaction mixture was measured at $734 \mathrm{~nm}$ with a spectrophotometer (Thermo Fischer Scientific, Model: G10S UV-Vis) for $15 \mathrm{~min}$ after initial mixing. The inhibition percentage was plotted as a function of concentration. The antioxidant activity of the pumpkin seed oils was calculated as Trolox Equivalent Antioxidant Capacity (TEAC). The TEAC was calculated from the ratio of the linear regression coefficient of pumpkin seed oil samples to that of the Trolox. The results were expressed as $\mu \mathrm{mol}$ Trolox equivalents per $\mathrm{g}$ of samples.

\subsection{Statistical analysis}

The study was conducted according to randomized block design using three replicates. The acquired data were subjected to variance analysis by using SPSS Statistics 21 package program and comparison of mean values was made using Duncan's test.

\section{Results and discussion}

\subsection{Basic characteristics of the pumpkin seed oils}

The specific gravity, refractive index, iodine number, saponification number, free fatty acid, p-anisidine, peroxide value, TBARS and viscosity values of the pumpkin seed oils are given in Table 1. Specific gravity is an important characteristic of vegetable oil and corresponds to the ratio of the weight of any substance given volume to the weight of an equal volume of water. Specific gravity values of the pumpkin seed oils ranged from 0.914 to 0.918 , which are within the range reported in the literature for vegetable oils: olive oil (0.910-0.916), rapeseed oil (0.910-0.920), sunflower seed oil (0.918-0.923) and pumpkin seed oil (0.923-0.926) (Nichols and Sanderson, 2003). The refractive index of saturated fatty acids a linear increase with chain length whereas the refractive index of unsaturated fatty acids increases with the degree of unsaturation. The refractive index of saturated fatty acids shows a linear increase with chain length whereas the refractive index of unsaturated fatty acids increases with the degree of unsaturation. The refractive index values of the pumpkin seed oils ranged from 1.472 to 1.473 , which are within the range reported in the literature for vegetable oils: olive oil $(1.468-1.471)$, rapeseed oil (1.465-1.469), sunflower seed oil (1.467-1.469) and pumpkin seed oil (1.466-1.474) (Nichols and Sanderson, 2003). Results presented in Table 1 show that pumpkin seed oils had high iodine number. The high iodine number can be related to indication of high unsaturated fatty acid content. The saponification number is considered as a measure of the average length of the fatty acids and varies inversely with the molecular weight. The values were similar to the saponification number of sunflower oil (188-194) and canola oil (182193) (Nichols and Sanderson, 2003).

Viscosity is a characteristic that is important in the design of industrial processes and it is also a factor that affects the stability of food. In general, saturated fatty acids have a higher viscosity value than unsaturated fatty acids. This is due to the fact that in saturated fatty acids carbon chains are arranged to be closer to each other, and hence they can establish intermolecular interactions such as Van der Waals forces. As can be seen in Table 1, the viscosity values measured in the present study (except for wet salted-roasted Nevşehir çerçevelisi) were lower than those reported by Ardabili et al. (2011), for $C$. pepo $(93.66 \mathrm{cp})$, while higher than those reported by Tsaknis et al. (1997) for $C$. maxima and $C$. pepo (72 cp). The viscosity values determined in pumpkin seed oils were higher than those reported by Nichols and Sanderson (2003) for olive oil (63.28), and maize oil (51.44). 


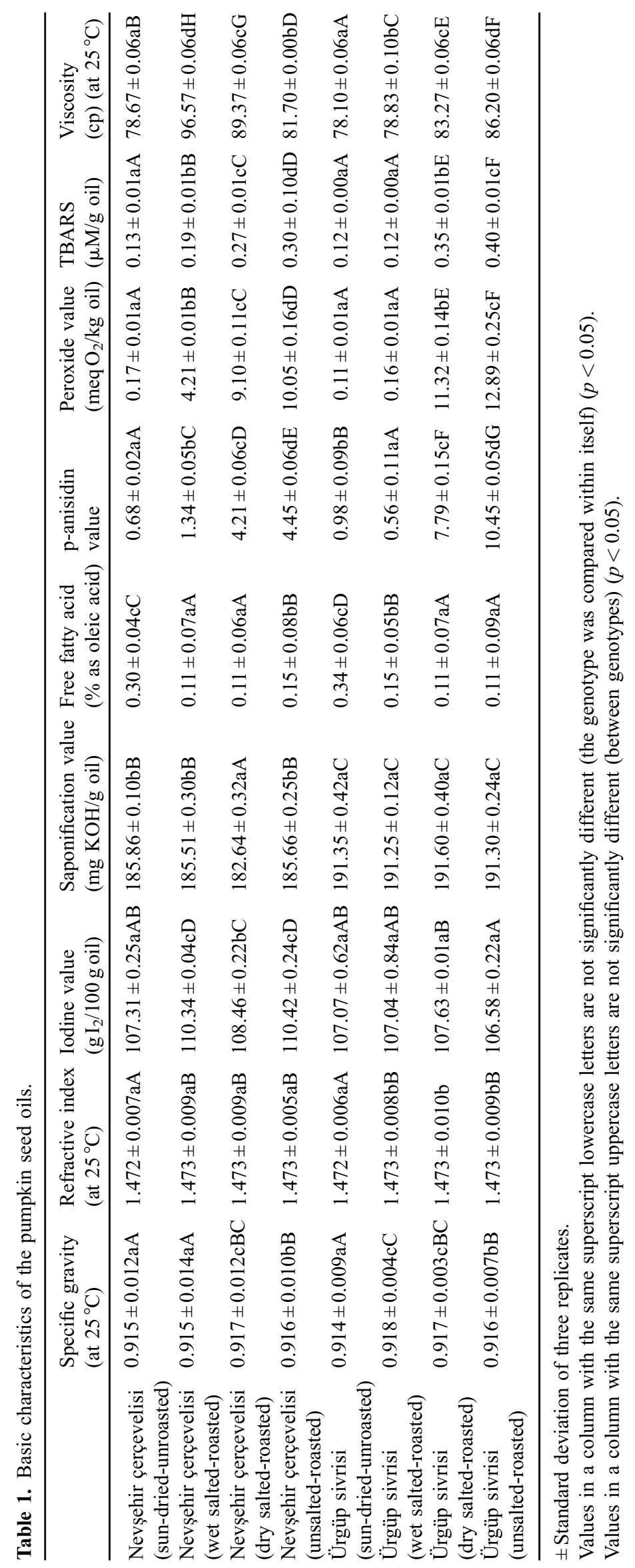

Page 5 of 10 
Table 2. L*, a* and $b^{*}$ values of the pumpkin seed oils.

\begin{tabular}{llll}
\hline & $\mathrm{L}^{*}$ & $\mathrm{a}^{*}$ & \\
\hline Nevşehir çerçevelisi (sun-dried-unroasted) & $9.55 \pm 0.24 \mathrm{bE}$ & $1.51 \pm 0.00 \mathrm{aA}$ & $\mathrm{b}^{*}$ \\
Nevşehir çerçevelisi (wet salted-roasted) & $9.48 \pm 0.35 \mathrm{bE}$ & $3.42 \pm 0.40 \mathrm{cD}$ & $1.71 \pm 0.02 \mathrm{aA}$ \\
Nevşehir çerçevelisi (dry salted-roasted) & $8.36 \pm 0.11 \mathrm{aC}$ & $2.49 \pm 0.24 \mathrm{aA}$ & $2.75 \pm 0.18 \mathrm{cC}$ \\
Nevşehir çerçevelisi (unsalted-roasted) & $8.47 \pm 0.10 \mathrm{aCD}$ & $1.39 \pm 0.38 \mathrm{bB}$ & $2.38 \pm 0.07 \mathrm{bB}$ \\
Ürgüp sivrisi (sun-dried-unroasted) & $7.97 \pm 0.08 \mathrm{bB}$ & $2.95 \pm 0.15 \mathrm{cD}$ \\
Ürgüp sivrisi (wet salted-roasted) & $7.45 \pm 0.07 \mathrm{baA}$ & $2.81 \pm 0.19 \mathrm{dE}$ & $2.75 \pm 0.03 \mathrm{aC}$ \\
Ürgüp sivrisi (dry salted-roasted) & $7.41 \pm 0.11 \mathrm{aA}$ & $2.70 \pm 0.03 \mathrm{cC}$ & $2.02 \pm 0.06 \mathrm{cF}$ \\
Ürgüp sivrisi (unsalted-roasted) & $8.76 .45 \pm 0.09 \mathrm{cD}$ & $2.14 \pm 0.09 \mathrm{bB}$ & $3.18 \pm 0.04 \mathrm{bE}$ \\
\hline
\end{tabular}

\pm Standard deviation of three replicates.

Values in a column with the same superscript lowercase letters are not significantly different (the genotype was compared within itself) $(p<0.05)$.

Values in a column with the same superscript uppercase letters are not significantly different (between genotypes) $(p<0.05)$.

Free fatty acid values of the pumpkin seed oils are shown in Table 1 . As can be seen from Table 1 , free fatty acid values were found higher $(p<0.05)$ in oils obtained from sun-driedunroasted seeds. The increase in the free fatty acid value of cold-pressed oils might be attributed to hydrolysis of triacylglycerols. Free fatty acid value in edible oils is one of the important qualitative parameter. There is an inversely proportional relationship between the edibility value of oil and the total amount of free fatty acid. A low amount of free fatty acid is a sign that the degree of edibility of the oil is high and the storage life is also high. The values of the free fatty acid in Table 1 represent that the oil samples maintained good quality as their acid values did not exceed (taking into account that the free fatty acid value is equal to the acid value divided by 1.99) the maximum limit of $4.0 \mathrm{mg} \mathrm{KOH} / \mathrm{g}$ of oil according to the Codex Alimentarius Commission (1999).

Peroxide value, which is based on the reduction of hydroperoxide group with iodine ion $\left(\mathrm{I}^{-}\right)$, provides information about hydroperoxide concentration. Among the oils extracted from differently treated pumpkin seeds, the highest peroxide value was observed in the unsalted-roasted and dry saltedroasted pumpkin seeds (Tab. 1). Peroxide values were found higher than 8 in these oil samples. However, peroxide values close to each other were obtained in the oils obtained from the wet salted seeds before roasting and the oils obtained from the sun-dried unroasted seeds (Tab. 1). This may be interpreted that the wet salting process is an effective process in preventing oxidation occurring during roasting process. The reason for this situation is considered to be fact that pumpkin seeds are kept for overnight in mixture of water and salt after adding water and salt to the seeds. The added water will have had enough time to penetrate overnight and will be absorbed by the seeds. The water absorbed by the shell of the seeds will the first evaporate during the roasting process and as the water evaporates this process will cause the shell to cool down. This will cause the heat effect to be perceived at a lower level within the seeds. This will ensure that the interior of the seed is less affected by the roasting conditions and that the moisture in the interior will evaporate towards the end of the roasting process. The reason for why this does not happen in salted and roasted pumpkin seeds is the fact that the time is not enough of the water to penetrate. Codex Alimentarius Commission (1999) states that peroxide value in refined vegetable oils should be no more 10 meq $\mathrm{O}_{2} / \mathrm{kg}$ oil, and the maximum value in cold-pressed and virgin oils should be $15 \mathrm{meq}_{2} / \mathrm{kg}$ oil. The reason for this situation is considered to be fact that pumpkin seeds are kept for overnight in mixture of water and salt after adding water and salt to the seeds.

p-anisidine value is a method used to determine the quantity of aldehydes (particularly 2-alkenals and 2.4alkadienals). In the studied oils, $\mathrm{p}$-anisidine values were low in the oils obtained from the wet salted seeds before roasting and the oils obtained from the sun-dried unroasted seeds (Tab. 1). On the other hand, higher values were obtained in oils extracted from dry salted-roasted and unsalted-roasted samples $(p<0.05)$.

The determination of TBARS is a common method to determine secondary oxidation products. The TBARS values obtained in all samples were below 1 (Tab. 1), which is the limit of acceptance of a product as rancid. Yoshida et al. (2006) reported that microwave roasting of pumpkin seeds resulted in only small increases after a long roasting period in peroxide value, carbonyl value, $\mathrm{p}$-anisidine value and TBARS.

\subsection{Color}

The $\mathrm{L}^{*}, \mathrm{a}^{*}$ and $\mathrm{b}^{*}$ values of the oils are shown in Table 2 . As seen in Table 2, roasting process resulted in increased darkness (lower $\mathrm{L}^{*}$ value) $(p<0.05)$. Positive $\mathrm{a}^{*}$ value is an indication of redness and this value was observed higher in oils extracted from the wet salted seeds before roasting $(p<0.05)$. On the other hand, positive $b^{*}$ value is an indication of yellow color intensity and in general, the yellow color intensity was found higher in roasted samples $(p<0.05)$. In a research conducted by Rezig et al. (2012) on oils extracted from C. maxima seeds, $\mathrm{L}^{*}$, $\mathrm{a}^{*}$ and $\mathrm{b}^{*}$ values were found to be 44.8 , -0.18 and 28.88 , respectively. As a result of a study of oil obtained from C. pepo seeds, $\mathrm{L}^{*}, \mathrm{a}^{*}$ and $\mathrm{b}^{*}$ values were found around 22, 10 and 40, respectively (Nyam et al., 2009).

\subsection{Mineral contents}

Mineral contents of pumpkin seed oils are shown in Table 3. Juranovic et al. (2003) used inductively coupled plasma atomic emission spectrometry (ICP-AES) to study 


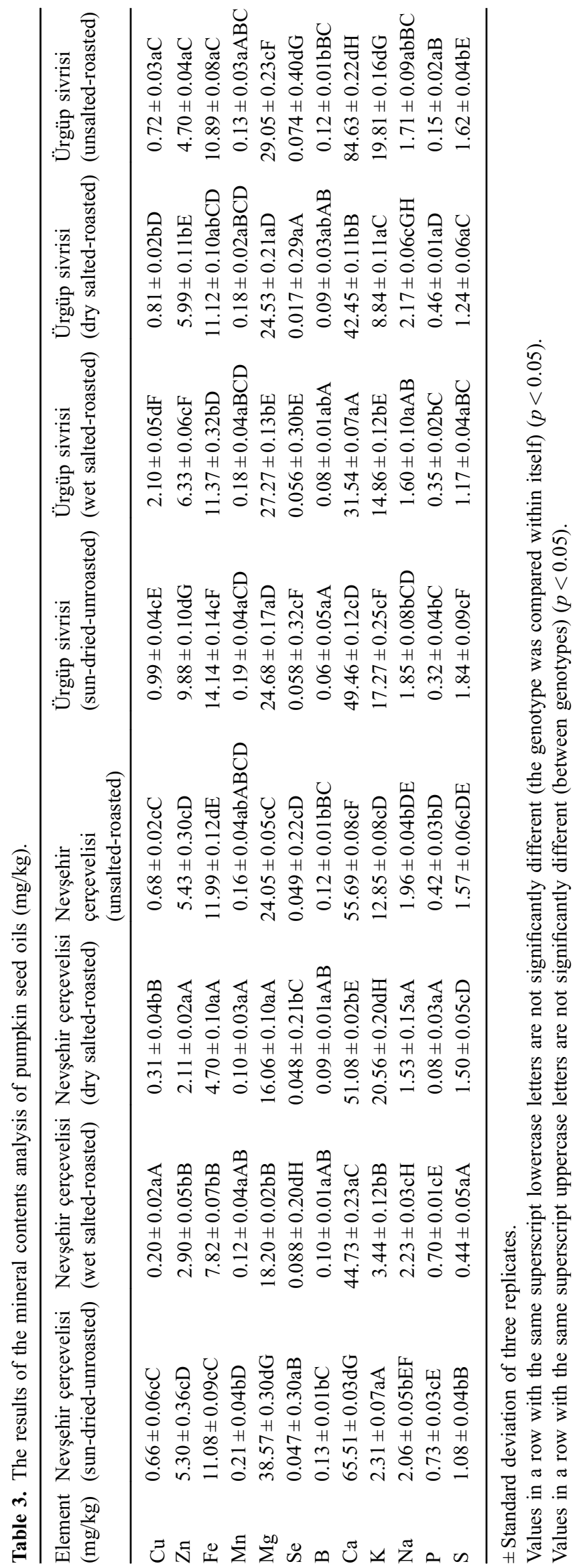

mineral content of pumpkin seed oils. Compared to their findings, the amount of $\mathrm{Cu}$ was higher than in our results, while the $\mathrm{Fe}$ and $\mathrm{Zn}$ contents were at about the same level. Bandoniene et al. (2013) observed that pumpkin seed oils from different geographic origins had different elemental characteristics. The content of metals found in oils differs depending on various factors. Metals can be incorporated into the seeds and oils from the soil or be introduced to oil during the production process. The presence of trace elements such as $\mathrm{Cu}, \mathrm{Fe}, \mathrm{Mn}$, $\mathrm{Ni}$ and $\mathrm{Zn}$ affect the oxidative stability of oils in different ways (Juranovic et al., 2003). The high levels of $\mathrm{Fe}$ and $\mathrm{Cu}$ concentrations significantly contribute to the deterioration of oil as they have redox potential and pro-oxidative effect. The phosphorus content in oils correlates positively with the severity of roasting process (Prevc et al., 2015). As a result of this research made by us, it was found that pumpkin seed oils are a rich source of $\mathrm{Zn}$. $\mathrm{Zn}$ is an essential micronutrient element for human health. Wessells and Brown (2012) reported that approximately $17.3 \%$ of the world's population was faced with the risk of $\mathrm{Zn}$ deficiency. $\mathrm{Zn}$ is an element that is present in the majority of the metabolic processes. It is the structural element of protein and biomembranes, as well as the role of the cofactor of various enzymes, also playing a role in the fulfillment of biological functions without the risk of inducing and oxidizing during the process of gene formation and transfer (Ovca et al., 2011). Because it is involved in so many different processes, $\mathrm{Zn}$ deficiency can lead to various disorders in the human body. There is no particular organ storing $\mathrm{Zn}$ in human body, therefore sufficient amounts of $\mathrm{Zn}$ must be taken from foods. The main source of many metals in foods is soil. $\mathrm{Zn}$ is found in much lower quantities in calcareous and sandy soils when compared to clay and volcanic soil.

Another important outcome of the study is that the oils is a rich source in terms of Se content too (Tab. 3). Similar to Zn, selenium is an important micronutrient element. Hurst et al. (2013) reported that, for both males and females, $55 \mu \mathrm{g} /$ day Se intake is necessary. Kubachka et al. (2017) emphasized that Se is not only an antioxidant, but it is also of vital importance for the development and functions of organs.

\subsection{Fatty acids}

The fatty acid compositions of the oils are given in Table 4 . As seen in the table, the samples contain high levels of unsaturated fatty acid. The results are similar to the results acquired by Stevenson et al. (2007). It is known that vegetable oils containing high levels of monounsaturated fatty acid (MUFA) (particularly oleic acid) are very effective in decreasing both cardio-vascular disease risk and infection (El-Adawy and Taha, 2001). Nutritional value of vegetable oils is determined by the ratio of MUFA/PUFA (polyunsaturated fatty acid) and theoretically MUFA offers more benefits than PUFA (Rabrenovic et al., 2014). Linoleic acid is an essential fatty acid and it is necessary for the formation of cellular membrane and different hormones. Pumpkin seed oil is a rich source both in oleic and in linoleic acid quantities, therefore it can be used as cooking and salad oil, as well as being suitable for margarine production. Having a high level of oleic acid is vital in terms of nutrition and it ensures high stability against 
cooking-frying. It has been reported that linoleic acid is oxidized 50 times faster than oleic acid and oil industry is trending towards sources with high oleic acid content (Rezig et al., 2012). Palmitoleic acid is described as "not detected" for the authenticity needs of pumpkin seed oil in the regulations of many European Union (EU) countries. In this study, as well as in other studies (Stevenson et al., 2007; Nederal et al., 2012; Nederal et al., 2014), presence of palmitoleic acid was observed. Therefore, as emphasized by Nederal et al. (2014) it is necessary to make a new regulation for this fatty acid in the pumpkin seed oils.

\subsection{Tocopherols}

The content of tocopherols of the oils are given in Table 5 . As a result of this research, the content of $\alpha$-tocopherol content could not be determined. As seen in Table $5, \beta+\gamma$ tocopherols content ranged from 131.78 to $881.77 \mathrm{mg} / \mathrm{kg}$ oil. On the other hand, $\delta$-tocopherol content ranged from 3.22 to $8.67 \mathrm{mg} / \mathrm{kg}$ oil. Tocopherols are natural antioxidants and their contents vary depending on the type of oil. Several factors, such as the climatic conditions of the material from which the vegetable oils are obtained, extraction process of the oil and the method of determining tocopherols affect the content (Rabrenovic et al., 2014). The results of this study were similar to those acquired by Rabrenovic et al. (2014). The researchers reported that the content of $\beta+\gamma$ tocopherols ranged from 29.92 to $53.60 \mathrm{mg} / 100 \mathrm{~g}$ oil, while the $\delta$-tocopherol content, which is an important form for oxidative stability, ranged from 3.39 to $10.44 \mathrm{mg} / 100 \mathrm{~g}$ oil. Murkovic et al. (2004) and Stevenson et al. (2007) emphasized that roasting process increased tocopherol content, while Yoshida et al. (2006) did not observe any significant changes and Gemrot et al. (2006) observed that 5 minutes of roasting at $140^{\circ} \mathrm{C}$ lead to significant reductions in tocopherol content. In this study, similar results were obtained by Gemrot et al. (2006) and in general, higher tocopherol contents were observed in sun-dried-unroasted pumpkin seed oils and the wet salted samples before roasting $(p<0.05)$. Butinar et al. (2011) stated that the content of $\delta$-tocopherol increases when the roasting time is increased from 10-12 min to $17-19 \mathrm{~min}$. As a result of this research carried out by us, no increase was detected in the tocopherol content due to roasting process. The short roasting time $(15 \mathrm{~min})$ is considered as the reason for this situation. Considering the tocopherol contents in Table 5 and the peroxide values in Table 1, it can be seen that the peroxide values were increased by decreasing the content of tocopherols. This may be explained by the fact that heat treatment increases oxidation in polyunsaturated lipids and leads to a consumption of antioxidants.

\subsection{Total phenolic compounds}

The total phenolic compounds of the oil samples were given in Table 5. As seen in the table, the treatments applied to the seeds before the oil were extracted had an insignificant effect on total phenolic compounds $(p>0.05)$. Veronezi and Jorge (2012) stressed that the roasting process resulted in a significant decrease in total phenolic compounds. However, such a result could not be obtained in this research. The total phenolic compounds found in the studied oils displayed 
Table 5. The tocopherol, total phenolics contents and antioxidant activity values of the oils extracted from differently treated pumpkin seeds.

\begin{tabular}{|c|c|c|c|c|}
\hline & $\begin{array}{l}\delta \text {-Tocopherol } \\
(\mathrm{mg} / \mathrm{kg})\end{array}$ & $\begin{array}{l}\beta+\gamma \text { Tocopherol } \\
(\mathrm{mg} / \mathrm{kg})\end{array}$ & $\begin{array}{l}\text { Total phenolic compounds } \\
\text { (mg EAG/g) }\end{array}$ & $\begin{array}{l}\text { TEAC } \\
(\mu \mathrm{mol} \text { Trolox } / \mathrm{g})\end{array}$ \\
\hline Nevşehir çerçevelisi (sun-dried-unroasted) & $4.82 \pm 0.31 \mathrm{cD}$ & $881.76 \pm 0.23 \mathrm{dH}$ & $2.24 \pm 0.13 \mathrm{aABC}$ & $1.10 \pm 0.01 \mathrm{cE}$ \\
\hline Nevşehir çerçevelisi (dry salted-roasted) & $3.84 \pm 0.28 \mathrm{bBC}$ & $302.77 \pm 0.22 b C$ & $2.30 \pm 0.16 \mathrm{aABC}$ & $1.00 \pm 0.01 \mathrm{bB}$ \\
\hline Nevşehir çerçevelisi (unsalted-roasted) & $4.08 \pm 0.16 \mathrm{bC}$ & $210.17 \pm 0.18 \mathrm{aB}$ & $2.31 \pm 0.13 \mathrm{aBC}$ & $0.96 \pm 0.01 \mathrm{aA}$ \\
\hline Ürgüp sivrisi (sun-dried-unroasted) & $6.22 \pm 0.19 \mathrm{bE}$ & $634.78 \pm 0.21 \mathrm{cF}$ & $2.18 \pm 0.03 \mathrm{aAB}$ & $1.07 \pm 0.01 \mathrm{bD}$ \\
\hline Ürgüp sivrisi (dry salted-roasted) & $3.65 \pm 0.20 \mathrm{aABC}$ & $131.77 \pm 0.20 \mathrm{aA}$ & $2.36 \pm 0.03 \mathrm{bC}$ & $1.03 \pm 0.01 \mathrm{aC}$ \\
\hline Ürgüp sivrisi (unsalted-roasted) & $3.52 \pm 0.26 \mathrm{aAB}$ & $617.70 \pm 0.28 \mathrm{bE}$ & $2.25 \pm 0.08 \mathrm{aABC}$ & $1.04 \pm 0.01 \mathrm{aC}$ \\
\hline
\end{tabular}

\pm Standard deviation of three replicates.

Values in a column with the same superscript lowercase letters are not significantly different (the genotype was compared within itself) $(p<0.05)$.

similarities to the results acquired by Veronezi and Jorge (2012). They found that the total phenolic compounds varied between 1.35 and $3.62 \mathrm{mgEAG} / \mathrm{g}$ in the lipid fraction of four different pumpkin seeds grown in Brazil. Andjelkovic et al. (2010) emphasized that total phenolic compounds varied depending on climatic and storage conditions, and time also had an important effect on content.

\section{7 $\mathrm{ABTS}^{+}$radical scavenging activity}

The radical scavenging activity values of the pumpkin seed oils are given in Table 5. As can be seen from Table 5, radical scavenging activity values in oils obtained from sun-driedunroasted seeds and roasted seeds after wet salting process were found to be higher than other oils. This is an indication that dry salted and unsalted roasting process leads to a significant decrease $(p<0.05)$ in radical scavenging activity. Similar results were reported by Xanthopoulou et al. (2009) and the researchers emphasized that radical scavenging activity varied depending on the total phenolic content, and extracts rich in phenolics had higher radical scavenging activity. Oloyede et al. $(2012 \mathrm{a}, \mathrm{b})$ emphasized that climatic conditions had a significant effect on the concentration of bioactive compounds, and mature pumpkin seeds had higher antioxidant activity than non-mature ones, and increased fertilizer quantity led to lower antioxidant activity. NawirskaOlszanska et al. (2013) reported that the seeds of the pumpkin varieties that belong to the species $C$. pepo exhibit better antioxidant properties than $C$. maxima, regardless of the extraction solvent used. The researchers also stated that $50 \%$ ethanol was more efficient than $80 \%$ methanol when used as an extracting agent, and the antioxidant activity values obtained with $50 \%$ ethanol were higher than those achieved with $80 \%$ methanol.

\section{Conclusion}

Results obtained from this study have shown that, if the pumpkin seeds are subjected to wet salting process overnight and then roasting process is carried out, both the quality criteria and antioxidant characteristics of the oil are maintained in the best way possible. Among the analyzed oil samples, four fatty acids (palmitic, stearic, oleic and linoleic acid) with high amounts were determined. From the results obtained, it is possible to indicate that pumpkin seed oil is a rich source in linoleic and oleic acid. In addition, because of the high content of the linoleic acid, this oil may be used as an essential oil acid source.

Acknowledgments. This work was supported by the Nevşehir Hacı Bektaş Veli University [Project no. NEÜBAP14F10, 2014].

\section{References}

Adams GG, Imran S, Wang S, et al. 2012. Extraction, isolation and characterisation of oil bodies from pumpkin seeds for therapeutic use. Food Chem 134: 1919-1925.

Andjelkovic M, Camp JV, Trawka A, Verhe R. 2010. Phenolic compounds and some quality parameters of pumpkin seed oil. Eur J Lipid Sci Technol 112: 208-217.

Anonymous. 1987. Standard Methods for Analysis of Oils, Fats and Derivates, International Union of Pure and Applied Chemistry, IUPAC Method 2.301, 7th ed. USA: Blackwell Scientific Publications.

AOCS. 2011. Official Methods and Recommended Practices of the American Oil Chemists' Society. Champaign, USA. Method Cd $18-90$.

Ardabili AG, Farhoosh R, Khodaparast MHH. 2011. Chemical composition and physicochemical properties of pumpkin seeds (Cucurbita pepo Subs. pepo Var. Styriaka) Grown in Iran. J Agric Sci Technol 13: 1053-1063.

Bandoniene D, Zettl D, Meisel T, Maneiko M. 2013. Suitability of elemental fingerprinting for assessing the geographic origin of pumpkin (Cucurbita pepo var. styriaca) seed oil. Food Chem 136: 1533-1542.

Bele C, Matea CT, Raducu C, Miresan V, Negrea O. 2013. Tocopherol content in vegetable oils using a rapid HPLC fluorescence detection method. Not Bot Horti Agrobo 41: 93-96.

Butinar B, Bucar-Miklavcic M, Mariani C, Raspor P. 2011. New vitamin $\mathrm{E}$ isomers (gamma-tocomonoenol and alpha-tocomonoenol) in seeds, roasted seeds and roasted seed oil from the Slovenian pumpkin variety 'Slovenska golica'. Food Chem 128: 505-512. 
Codex Alimentarius Commission. 1999. Codex standards for fats and oils from vegetable sources. (Codex-Stan 210 - 1999). FAO/WHO.

El-Adawy T, Khaled M. 2001. Characteristics and composition of watermelon, pumpkin and paprika seed oils and flours. J Agric Food Chem 49: 1253-1259.

FAO. 2010. Fats and fatty acids in human nutrition. Report of an expert consultation. FAO Food and Nutrition Paper 91.

Gemrot F, Barouh N, Vieu JP, Pioch D, Montet D. 2006. Effect of roasting on tocopherols of gourd seeds (Cucurbita pepo). Gras Aceit 57: 409-414.

Hurst R, Collings R, Harvey LJ, et al. 2013. EURRECA—Estimating selenium requirements for deriving dietary reference values. Crit Rev Food Sci Nutr 53: 1077-1096.

Jiao J, Li ZG, Gai QY, et al. 2014. Microwave-assisted aqueous enzymatic extraction of oil from pumpkin seeds and evaluation of its physicochemical properties, fatty acid compositions and antioxidant activities. Food Chem 142: 17-24.

Juranovic I, Breinhoelder P, Steffan I. 2003. Determination of trace elements in pumpkin seed oils and pumpkin seeds by ICP-AES. J Anal At Spectrom 18: 54-58.

Ke PJ, Woyewodo AD. 1979. Microdetermination of thiobarbituric acid values in marine lipids by a direct spectrophotometric method with a monophasic reaction system. Analy Chim Acta 106: 279-284.

Kim MY, Kim EJ, Kim YN, Choi C, Lee BH. 2012. Comparison of the chemical compositions and nutritive values of various pumpkin (Cucurbitaceae) species and parts. Nutr Res $\operatorname{Pr} 6$ : 21-27.

Kubachka KM, Hanley T, Mantha M, et al. 2017. Evaluation of selenium in dietary supplements using elemental speciation. Food Chem 218: 313-320.

Murkovic M, Piironen V, Lampi AM, Kraushofer T, Sontag G. 2004. Changes in chemical composition of pumpkin seeds during the roasting process for production of pumpkin seed oil (Part 1: nonvolatile compounds). Food Chem 84: 359-365.

Nawirska-Olszanska A, Kita A, Biesiada A, Skol-Letowska A. 2013. Characteristics of antioxidant activity and composition of pumpkin seed oils in 12 cultivars. Food Chem 139: 155-161.

Nederal S, Skevin D, Kraljic K, Obranovic M, Papesa S, Bataljaku A. 2012. Chemical composition and oxidative stability of roasted and cold pressed pumpkin seed oils. J Am Oil Chem Soc 89: 1763-1770.

Nederal S, Petrovic M, Vincek D, et al. 2014. Variance of quality parameters and fatty acid composition in pumpkin seed oil during three crop seasons. Ind Crop Prod 60: 15-21.

Nichols DS, Sanderson K. The nomenclature structure and properties of food lipids. In Sikorski ZE, Kolakowska A, eds.Chemical and functional properties of food lipids. New York: CRC Press, 2003, pp. 1-31).

Nielson SS. 2003. Food Analysis Laboratory Manual. New York: Kluwer Academic/Plenum Publishers.

Nyam KL, Tan CP, Lai OM, Long K, Che Man YB. 2009. Physicochemical properties and bioactive compounds of selected seed oils. LWT-Food Sci Technol 42: 1396-1403.

Ockerman HW. 1985. Quality control of post mortem muscle tissue. Ohio: The Ohio Agricultural Research and Development Center.

Oloyede FM, Obisesan IO, Agbaje GO, Obuotor EM. 2012a. Effect of NPK fertilizer on chemical composition of pumpkin (Cucurbita pepo Linn.) seeds. Sci World J: 1-6.
Oloyede FM, Agbaje GO, Obuotor EM, Obisesan IO. 2012b. Nutritional and antioxidant profiles of pumpkin (Cucurbita pepo Linn.) immature and mature fruits as influenced by NPK fertilizer. Food Chem 135: 460-463.

Ovca A, van Alteren JT, Falnoga I, Selih VS. 2011. Speciation of zinc in pumpkin seeds (Cucurbita pepo) and degradation of its species in the human digestive tract. Food Chem 128: 839-846.

Paradiso VM, Clemente A, Summo C, Pasqualone A, Caponio F. 2016. Towards green analysis of virgin olive oil phenolic compounds: Extraction by natural deep eutectic solvent and direct spectrophotometric detection. Food Chem 212: 43-47.

Pericin D, Krimer V, Trivic S, Radulovic L. 2009. The distribution of phenolic acids in pumpkin's hull-less seed, skin, oil cake meal, dehulled kernel and hull. Food Chem 113: 450-456.

Prevc T, Segatin N, Ulrih N.P., Cigic B. 2013. DPPH assay of vegetable oils and model antioxidant in protic and aprotic solvents. Talanta 109: 13-19.

Prevc T, Segatin N, Kralj P, Ulrih NP, Cigic B. 2015. Influence of metal ions and phosholipids on electrical properties: A case study on pumpkin seed oil. Food Control 54: 287-293.

Rabrenovic BB, Dimic EB, Novakovic MM, Tesevic VV, Basic ZN. 2014. The most important bioactive components of cold pressed oil from different pumpkin (Cucurbita pepo L.) seeds. LWT-Food Sci Technol 55: 521-527.

Re R, Pelegrini N, Protegggente A, Pannala A, Yang MR, Ce-Evans C. 1999. Antioxidant activity applying an improved ABTS radical cation decolorization assay. Free Radic Biol Med 26: 1231-1237.

Rezig L, Chouaibi M, Msaada K, Hamdi S. 2012. Chemical composition and profile characterisation of pumpkin (Cucurbita maxima) seed oil. Ind Crop Prod 37: 82-87.

Saucedo-Hernandez Y, Lerma-Garcia MJ, Herrero-Martinez JM, Ramis-Ramos G, Jorge-Rodriguez E, Simo-Alfonso F. 2011. Classification of pumpkin seed oils according to their species and genetic variety by attenuated total reflection Fourier Transform Infrared Spectroscopy. J Agric Food Chem 59: 4125-4129.

Stevenson DG, Eller FJ, Wang L, Jane JL, Wang T, Inglett GE. 2007. Oil and tocopherol content and composition of pumpkin seed oil in 12 cultivars. J Agric Food Chem 55: 4005-4013.

Tsaknis J, Lalas S, Lazos ES. 1997. Characterization of crude and purified pumpkin seed oil. Gras Aceit 48: 267-272.

TUIK, 2016.Türkiye İstatistik Kurumu Bitkisel Üretim İstatistikleri, Ankara, Turkey.

Veronezi CM, Jorge N. 2012. Bioactive compounds in lipid fractions of pumpkin (Cucurbita sp) seeds for use in food. J Food Sci 77: C653-C657.

Wessells KR, Brown KH. 2012. Estimating the global prevalence of zinc deficiency: Results based on zinc availability in national food supplies and the prevalence of stunting. Plos One 7: 1-11.

Xanthopoulou MN, Nomikos T, Fragopoulou E, Antonopoulou S. 2009. Antioxidant and lipoxygenase inhibitory activities of pumpkin seed extracts. Food Res Int 42: 641-646.

Yoshida H, Tomiyama Y, Hirakawa Y, Mizushina Y. 2006. Microwave roasting effects on the oxidative stability of oils and molecular species of triacylglycerols in the kernels of pumpkin (Cucurbita spp.) seeds. J Food Compos Anal 19: 330 339.

Cite this article as: Aktaş N, Gerçekaslan KE, Uzlaşır T. 2018. The effect of some pre-roasting treatments on quality characteristics of pumpkin seed oil. OCL 25(3): A301. 